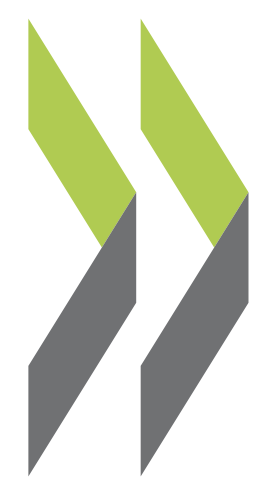

OECD Economics Department Working Papers No. 1103

The Effect of Government Debt, External Debt David Turner, and their Interaction Francesca Spinelli on OECD Interest Rates 
Organisation de Coopération et de Développement Économiques

Organisation for Economic Co-operation and Development

11-Dec-2013

ECONOMICS DEPARTMENT

English - Or. English

THE EFFECT OF GOVERNMENT DEBT, EXTERNAL DEBT AND THEIR INTERACTION ON OECD INTEREST RATES

ECONOMICS DEPARTMENT WORKING PAPERS No. 1103

By David Turner and Francesca Spinelli

All Economics Department Working Papers are available through OECD's Internet website at www.oecd.org/eco/Workingpapers

JT03350332

Complete document available on OLIS in its original format

This document and any map included herein are without prejudice to the status of or sovereignty over any territory, to the delimitation of international frontiers and boundaries and to the name of any territory, city or area. 


\section{ABSTRACT/RESUME}

\section{The effect of government debt, external debt and their interaction on OECD interest rates}

In the wake of the financial crisis there has been renewed focus on the importance of a country's net external debt position in determining domestic interest rates and, relatedly, its vulnerability to a crisis. This paper extends the panel estimation of OECD countries described in Turner and Spinelli (2012) to investigate the effect of external debt and its interaction with government debt on the interest-rate-growth differential. The inclusion of net external debt is found to be significant in both economic and statistical terms, and of particular importance for euro area countries in the post-crisis period. The results imply that the interest-rate effect of marginal increases in external debt or government debt is non-linear and dependent on the initial levels of debt, with the interest rate effect rising sharply in the post-crisis period for euro area countries which have a combination of both high external debt and high government debt. The policy implications for those countries under financial market pressure, especially within the euro area, are that reducing external deficits and debt are at least as important as reducing government deficits and debt. In any case, the effect of higher net external debt on interest rates provides a feedback effect which may prevent countries running sustained large current account imbalances over a long period. However, evidence of an asymmetry in the effect (between the effect of net external debt and net external assets) suggests that the pressure for adjustment will apply more strongly to deficit countries. It also implies that increased polarisation of external debt positions will raise the overall level of global interest rates.

JEL classification: E43; E62; H63; H68

Keywords: fiscal sustainability, government debt, external debt, interest rates, interest-rate-growth differential

$$
* * * * * * * * * * * * * * * * * * * * * * * * * * *
$$

\section{L'effet de la dette publique, de la dette extérieure et de leur interaction sur les taux d'intérêt dans la zone OCDE}

À la suite de la crise financière, il y a eu un nouvel intérêt porté à l'importance de la position nette extérieure d'un pays dans la détermination des taux d'intérêt domestique, et par conséquent, sa vulnérabilité à une crise. Ce papier étend l'estimation de panel des pays de l'OCDE décrit dans Turner et Spinelli (2012) afin d'étudier l'effet de la dette extérieure et de son interaction avec la dette publique sur l'écart entre le taux d'intérêt et le taux de croissance. La prise en compte de la position nette extérieure apparait significative à la fois en termes économiques et statistiques, et notamment pour les pays de la zone euro dans la période postérieure à la crise. Les résultats soulignent que l'effet de la dette extérieure ou publique sur le taux d'intérêt est non linéaire et dépend des niveaux initiaux de dette ; en particulier l'effet sur le taux d'intérêt augmente beaucoup après la crise pour les pays de la zone euro du fait de la présence simultanée d'une dette extérieure et publique élevée. La conséquence en terme de politique économique pour ces pays sous pression des marchés financiers, spécialement dans la zone euro, est que la réduction des déficits et dettes extérieurs est au moins aussi importante que la réduction des déficits et dettes publics. Dans tous les cas, l'effet d'une dette extérieure nette élevée sur les taux d'intérêt se conjugue à un effet rétroactif qui peut empêcher un pays d'avoir des déséquilibres récurrents de balance courante sur une longue période. Cependant, l'existence d'une asymétrie de l'effet (entre l'effet d'une dette ou d'un surplus extérieur) suggère que la pression à l'ajustement va s'exercer plus fortement sur des pays avec des déficits. Cela implique également que la polarisation accrue sur les positions nettes extérieures va augmenter le niveau global des taux d'intérêt.

Classification JEL : E43 ; E62 ; H63 ; H68

Mots clé : viabilité budgétaire, dette extérieure, taux d'intérêt, écart taux d'intérêt, taux de croissance

(C) OECD (2013)

You can copy, download or print OECD content for your own use, and you can include excerpts from OECD publications, databases and multimedia products in your own documents, presentations, blogs, websites and teaching materials, provided that suitable acknowledgment of OECD as source and copyright owner is given. All requests for commercial use and translation rights should be submitted to rights@oecd.org. 
TABLE OF CONTENTS

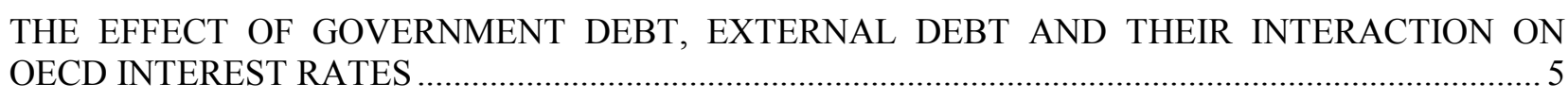

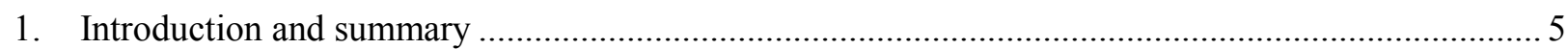

2. The framework for explaining the interest-rate-growth differential ............................................. 7

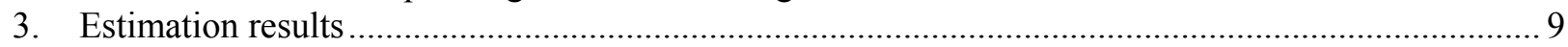

4. Effects of government debt and external debt on interest rates .................................................... 12

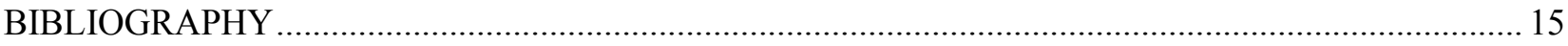

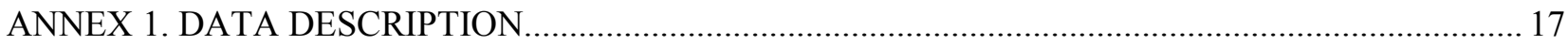

ANNEX 2. A BRIEF SELECTIVE SUMMARY OF THE LITERATURE RELATING EXTERNAL

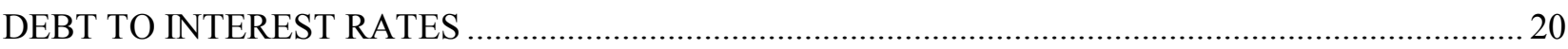

ANNEX 3. SENSITIVITY OF THE RESULTS TO RELAXING THE RESTRICTION ON NOMINAL

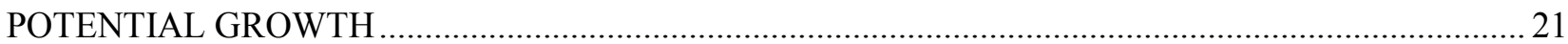

\section{Tables}

1. Panel regression results explaining the interest-rate-growth differential for 22 OECD countries... 10

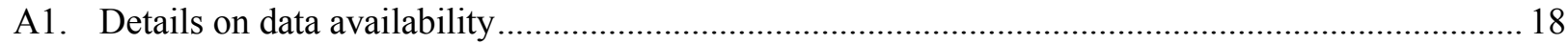

A2. List of countries composing the different aggregates considered in the empirical analysis ............ 19

A3. Panel regression results from relaxing the restriction on nominal potential growth...................... 21

\section{Figures}

1. The interest-rate-growth differential for 22 OECD countries.

2. OECD countries for which gross government debt exceeds $75 \%$ of GDP ................................... 8

3. Net external-debt-to-GDP ratio of selected OECD countries .................................................. 9

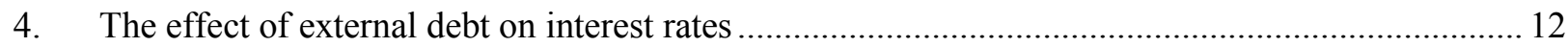

5. Risk premia effects of different combinations of external and government debt ......................... 13

6. Risk permia effects of an increase in the government-debt-to-GDP ratio by 1 percentage point.... 14 
ECO/WKP(2013)95 
ECO/WKP(2013)95

\title{
THE EFFECT OF GOVERNMENT DEBT, EXTERNAL DEBT AND THEIR INTERACTION ON OECD INTEREST RATES
}

\author{
by \\ David Turner and Francesca Spinelli ${ }^{1}$
}

\section{Introduction and summary}

1. In the wake of the financial crisis there has been renewed focus on the importance of a country's net external debt position in determining domestic interest rates and, relatedly, its vulnerability to a crisis. Catao and Milesi-Ferretti (2012) find using an up-to-date sample of advanced and emerging economies that there is a strong effect of net external liabilities on external crisis risk. Within the European Monetary Union, Gros (2013) argues that the wide variation in interest rates on government bonds is better explained by external debt than government debt. The ability of Japan to accumulate ever higher government debt without escalating interest rates is often explained by its ability to finance government debt domestically and its high level of net external assets (for example: OECD, 2013; Kawai and Morgan, 2012).

2. The empirical framework employed in this paper extends Turner and Spinelli (2012) to investigate the effect of external debt and its interaction with government debt on the interest-rate-growth differential. The earlier work, using a panel estimation of OECD countries, found important effects on this differential from inflation volatility, the slope of the yield curve, a measure of the "global savings glut" and government debt. The main findings of the current paper relating to the effect of external debt and government debt are as follows:

- The inclusion of net external debt is significant in explaining the interest-rate-growth differential in both economic and statistical terms, although important differences are found for euro area countries when the estimation period is extended to include the post-crisis period. For a country with existing net external debt an increase in the ratio of net external debt to GDP by 1 percentage point is estimated to raise the interest-rate-growth differential by about $2 \frac{1}{2}$ basis points, which is similar to other estimates in the literature.

- An important difference with the existing literature is, however, that when tested separately, the effect of changes in net external debt on the interest-rate-differential is found to be weaker for a country which starts from a positive net external asset position compared to one which starts from a net external debt position. Hence, the interest-rate "penalty" for high external indebtedness is larger than the interest rate reduction for an equivalent net external asset position.

1. David Turner is Head of the Macroeconomic Analysis Division of the OECD Economics Department, Francesca Spinelli formerly worked in that Division, but now works for the Trade in Services Division of the Trade and Agriculture Directorate. They would like to thank Jean-Luc Schneider, Yvan Guillemette, Jan Strasky and participants at the 2013 Project Link meeting for helpful comments on the paper as well as Diane Scott for help in the final document preparation. The views expressed in this paper are those of the authors and do not necessarily represent those of the OECD or its member countries. 
- Compared to the results in the earlier study, the effect of government debt on the interest-ratedifferential is more heterogeneous, depending on the extent to which it is accompanied by an increase in external debt. Thus in the earlier paper the effect of an increase in general government debt by 1 percentage point of GDP (evaluated relative to a threshold of $75 \%$ of GDP) was found to increase interest rates by about 4 basis points. In the current study, the effects of an increase in government debt (in each case evaluated relative to an initial threshold of $75 \%$ of GDP) for noneuro-area countries is about $2 \frac{1}{2}$ basis points if financed entirely domestically and about $3 \frac{1}{2}$ to 5 basis points if it is financed externally (being higher if the country starts from a position of net external debt).

- In the post-crisis period, there is evidence of increased sensitivity of euro area interest rates to both government and external debt, which provides some quantification of the increased vulnerability of countries within a monetary union arising from the separation of decisions about debt issuance and monetary control (De Grauwe, 2011). The preferred specification includes a non-linear variable which is a combination of both government and external debt and helps to explain much of the recent extreme movements in euro area interest rates. It implies that the marginal effects of increases in government and external debt depend strongly on initial debt levels. For example, a 1 percentage point increase in the government-debt-to-GDP ratio above the $75 \%$ threshold varies as follows: for countries which start with positive net external assets the interest rate effect is the same as for non-euro-area countries (about $2 \frac{1}{2}$ basis points); for countries with net external debt of about $25 \%$ of GDP (similar to Italy) the increase in interest rates is more than double that (about $5 \frac{1}{2}$ basis points); but for a country with initial net external debt of $100 \%$ of GDP (similar to Greece, Portugal, Ireland and Spain) the corresponding increase in interest rates is nearly five times greater (about 12 basis points). While the magnitudes of these effects reflect particular financial market tensions over the estimation period, which have subsequently eased, they do suggest that those euro area countries with a combination of both high external and government debt may be most vulnerable during a period of heightened financial market tension.

3. The policy implications for countries under financial market pressure, especially those within the euro area, are that reducing external deficits and debt may be at least as important as reducing government deficits and debt. In any case, the effect of higher net external debt on interest rates provides a feedback effect which will likely prevent countries running sustained large current account imbalances over a long period. ${ }^{2}$ However, evidence of an asymmetry in the effect (between the effect of net external debt and net external assets) suggests that the pressure for adjustment will apply more strongly to deficit countries. It also implies that increased polarisation of external debt positions will raise the overall level of global interest rates.

4. The remainder of the paper is organised as follows: the next section sets out the empirical framework for the analysis; section 3 reports estimation results; section 4 considers the policy implications of the results, focusing on the interest rate implications of government and external debt. The data used in the empirical work is described in more detail in Annex 1 and there is a brief selective review of some of the literature concerning the effect of external debt on interest rates in Annex 2. Lastly, Annex 3 reports the sensitivity of the results to relaxing the restriction on nominal potential growth.

2. Indeed, these results have been used to calibrate the OECD's long-term projection model (Johannson, et a1, 2012) so that increasing net external debt puts upwards pressure on domestic interest rates and this tends to lower investment and rein in the current account deficit. 


\section{The framework for explaining the interest-rate-growth differential}

5. For the purposes of the empirical estimation, the interest-rate-growth differential is measured as the difference between the interest rate on 10-year government bonds and a smoothed OECD estimate of nominal potential growth. This measurement of the differential differs in several important respects from that included in the familiar identity linking government debt and the primary balance, but is a more practical measure for the purpose of estimation, particularly because of greater cross-country comparability (see Turner and Spinelli, op cit., for further discussion).

6. A positive link between long-term interest rates and potential growth can be derived from microeconomic foundations (Laubach, 2009), although such a derivation does not necessarily imply a unit coefficient on growth. Such a restriction is imposed here so that the results are more readily comparable with Turner and Spinelli (2012). If this restriction is relaxed, the coefficient on nominal potential growth is estimated to be about 0.7 , although the coefficients on the government and external debt only change marginally (as discussed in Annex 3 which examines the sensitivity of the results to the relaxation of this restriction).

7. Based on this definition, the interest-rate-growth differential for 22 OECD countries shows a marked fall, from its median level in the 1980 s and first half of the 1990 s of typically about $2 \frac{1}{2}$ percentage points, to close to zero during the pre-crisis 2000s (Figure 1). Moreover, there are many countries (e.g. Australia, Canada, Denmark, Spain, Ireland and Norway) where the interest rate-growth-differential fell by 4 percentage points or more between these two periods. Following the financial crisis, there has been much greater dispersion in the differential; the differential for the median country fell below -1 percentage point in 2012 (its lowest level since 1980), while for some of the euro area countries under financial market pressure the differential soared, notably exceeding 20 percentage points for Greece in 2012.

Figure 1. The interest-rate-growth differential for 22 OECD countries

Percentage points

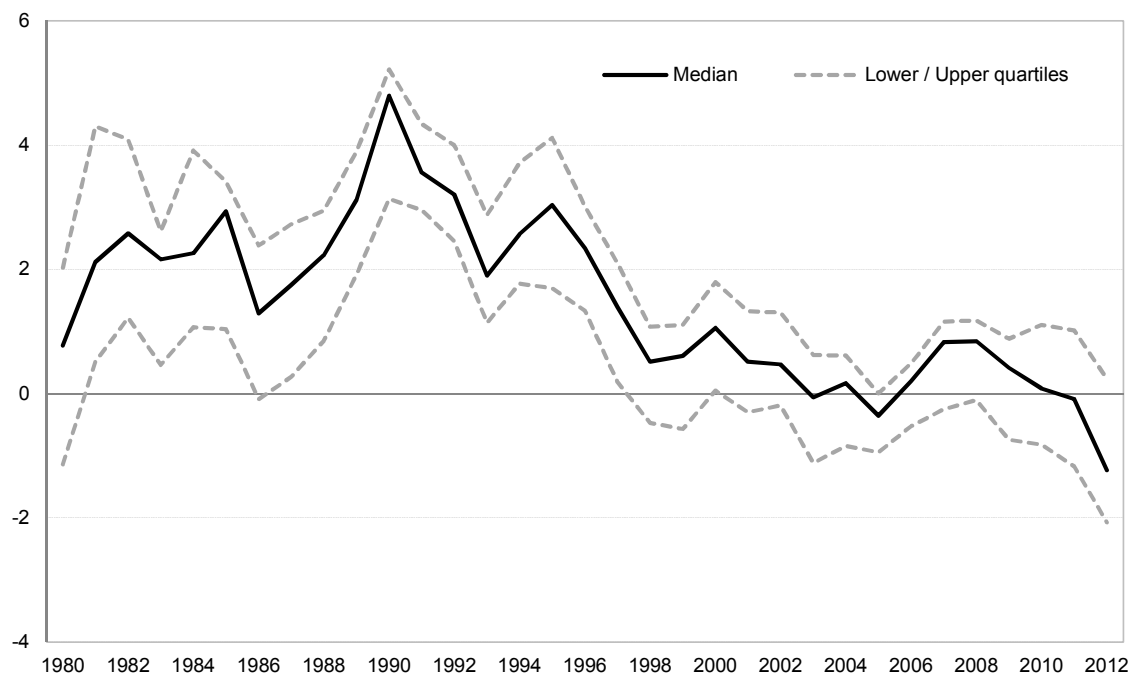

Source: OECD Economic Outlook November 2013 and OECD calculations, for further details on the data see Annex 1.

8. The basic empirical framework for explaining the interest-rate-growth differential is similar to that employed by Turner and Spinelli (2012) with explanatory variables as follows: 
- A measure of the volatility of inflation, here taken to be the 10-year standard deviation of CPI inflation, which is considered as a proxy for uncertainty surrounding inflation, with a prior being that reduced uncertainty/volatility will imply a lower interest-rate-differential.

- A measure of the slope of the yield curve, here taken to be the difference between lagged shortterm interest rates and a four-year lagged average of long-term interest rates, which is included to allow for the influence of policy interest rates. Thus, low policy rates, by creating expectations of future low short-term interest rates, are likely to drag down current long-term interest rates.

- A proxy for the "global savings glut" originating from Asian emerging markets and oil exporters, taken to be an ex-post measure of these countries' current account balances, with a prior being that this variable will tend to reduce the interest-rate-differential for all OECD countries, as argued by Bernanke $(2005,2007)$ in relation to the United States.

- A measure of government indebtedness, taken to be the excess of the gross government debt-toGDP ratio above $75 \%$, where this threshold is the one that is used in modelling long-term interest rates for the OECD Economic Outlook projections. ${ }^{3}$ The number of countries for which government debt has risen above this threshold has increased substantially in the aftermath of the crisis (Figure 2).

Figure 2. OECD countries for which gross government debt exceeds $75 \%$ of GDP

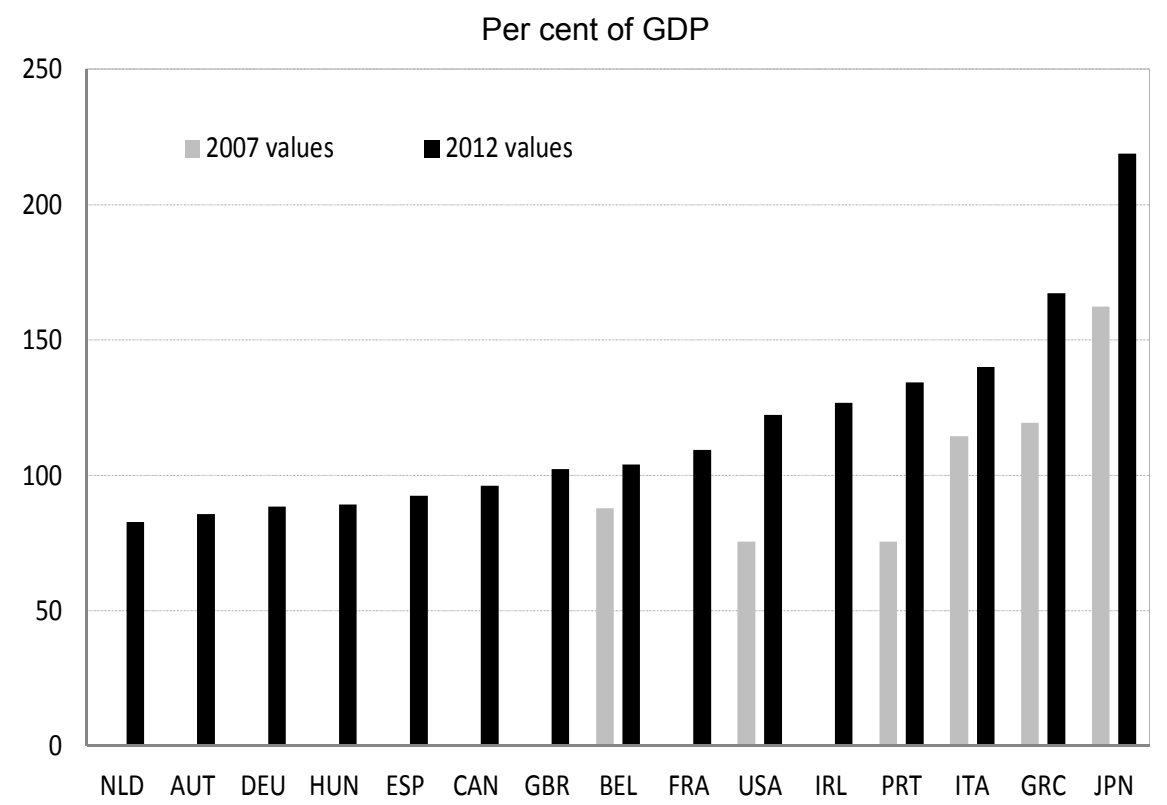

Note: Although reported in the chart, Hungary (HUN) has not been included in the empirical analysis.

Source: OECD Economic Outlook November 2013 and OECD calculations.

9. These explanatory variables are supplemented with a measure of the net external indebtedness of a country, given a number of empirical multi-country studies find an effect on interest rates (see Annex 2). The net external debt positions among OECD countries have tended to become more polarised over the

3. No particular precision should be attached to the $75 \%$ debt threshold, rather there are a range of studies (including Egert, 2010, Laubach, 2009 and Sutherland et al., 2012) that suggest that government debt ratios in excess of levels of between $60 \%$ and $90 \%$ have an effect on interest rates. 
sample period (Figure 3): Greece, Portugal, Ireland and Spain have all substantially increased their net external debt positions with the net external debt ratios exceeding or approaching $100 \%$ of GDP; whereas Germany, Japan, Belgium, Norway and Switzerland have all built up net external asset positions.

Figure 3. Net external-debt-to-GDP ratio of selected OECD countries

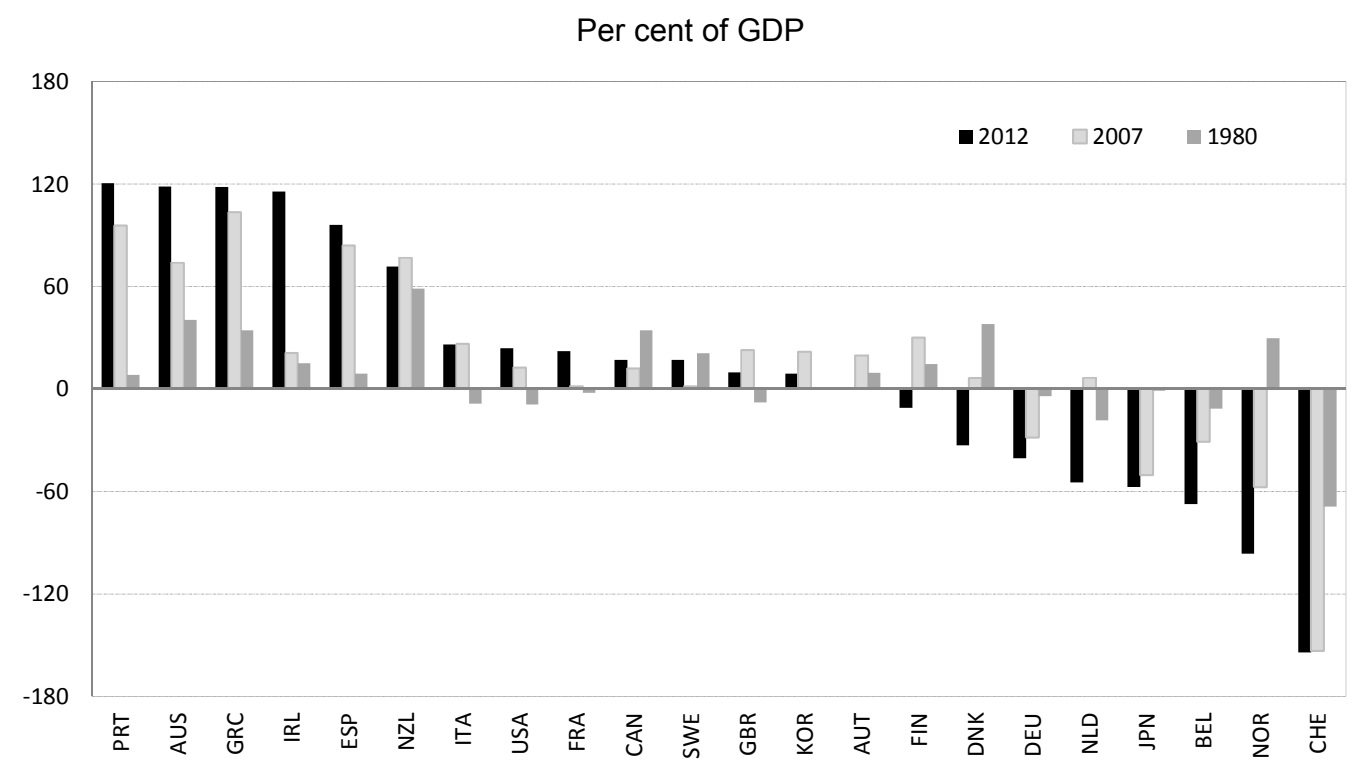

Note: The first ratio refers to 1980 or the earliest year available. See Table A1 in Annex 1 for details on the time period covered for each country's net external position.

Source: IMF International Financial Statistics, November 2013, see Annex 1 for further details on the data.

\section{Estimation results}

10. The estimation is run for 22 OECD countries (chosen for reasons of data availability) on a sample period which extends from 1980 to 2012 (Table 1). ${ }^{4}$ The interpretations of the coefficients on variables which are common across a range of specifications are as follows:

- Inflation variability is consistently significant and positive and implies that the median reduction in inflation variability of $3 \frac{1}{2}$ percentage points between the 1980 s and the 2000 s would have reduced the interest-growth-differential by about $3 / 4$ percentage point, although by much more in some countries.

- The measure of the yield curve slope is positive and significant implying that for every percentage point difference between current short-term interest rates and lagged long-term rates, current long-term interest rates will be pulled about 20 to 25 basis points in the same direction.

- The "global savings glut" variable is strongly significant and implies that over the pre-crisis 2000 s the interest-rate-growth differential for all OECD countries was reduced by just over 1 percentage point compared to the 1980s and 1990s.

4. The panel is unbalanced, because there are some countries for which data is not complete over the full sample period. Further details are given in Annex 1. 
ECO/WKP(2013)95

Table 1. Panel regression results explaining the interest-rate-growth differential for 22 OECD countries

Sample 1980-2012, Dependent variable: interest-rate-growth differential

\begin{tabular}{|c|c|c|c|c|c|c|c|c|}
\hline & (1) & (2) & (3) & (4) & (5) & (6) & (7) & (8) \\
\hline $\operatorname{Var}(\pi)$ & $0.177^{\text {** }}$ & 0.192 ** & $0.215 * * *$ & $0.241^{\star \star * *}$ & $0.199 * * *$ & 0.148 ** & $0.169 * * *$ & $0.180^{* * *}$ \\
\hline Ycurve & $0.180 * \star *$ & $0.189^{* * *}$ & $0.202^{* * *}$ & $0.168^{* * *}$ & $0.233^{\star \star *}$ & $0.246^{* * *}$ & $0.238 * * *$ & $0.241^{* \star *}$ \\
\hline s Glut & $-1.715^{* * *}$ & $-1.595^{* * *}$ & $-1.784^{* * *}$ & $-1.638 * * *$ & $-1.742 * * *$ & $-1.763^{* * *}$ & $-1.651 * * *$ & $-1.637 * * *$ \\
\hline GDebt & $0.050 * \star *$ & $0.048^{* \star *}$ & $0.043^{* * *}$ & $0.046^{\star * *}$ & $0.029 * * *$ & $0.026^{* * *}$ & $0.023 * * *$ & $0.025^{* * *}$ \\
\hline NXD & & $0.031^{* * *}$ & & & & & & \\
\hline$N X D>0$ & & & $0.045^{\star * *}$ & $0.045^{* * *}$ & $0.030 * * *$ & $0.020^{* * *}$ & $0.024 * * *$ & $0.025^{* * *}$ \\
\hline$N X D<0$ & & & 0.012 * & $0.015^{* *}$ & $0.015^{* *}$ & $0.014^{* *}$ & 0.011 ** & 0.011 ** \\
\hline D_USA & & & & $-4.040^{* * *}$ & -2.953 ** & $-2.675^{* *}$ & -2.652 ** & $-2.746^{* *}$ \\
\hline D_GRC & & & & & & & & $8.338 * * *$ \\
\hline D_EMU*GDebt & & & & & $0.102 * * *$ & $0.064^{* * *}$ & & \\
\hline D_EMU*NXD>0 & & & & & & $0.039 * \star \star$ & & \\
\hline D_EMU*NXD>0*Gdebt & & & & & & & $0.148 * * *$ & $0.123 * * *$ \\
\hline Number of observations & 640 & 609 & 609 & 609 & 609 & 609 & 609 & 609 \\
\hline Adj R-squared & 0.31 & 0.38 & 0.39 & 0.42 & 0.53 & 0.55 & 0.60 & 0.61 \\
\hline S.E. of regression & 1.99 & 1.81 & 1.79 & 1.75 & 1.56 & 1.53 & 1.45 & 1.43 \\
\hline Country fixed effects & yes & yes & yes & yes & yes & yes & yes & yes \\
\hline Country dummies & no & no & no & yes & yes & yes & yes & yes \\
\hline
\end{tabular}

Notes: Variable definitions as follows (see Annex 1 for further details): $\operatorname{Var}(\pi)=$ measure of the variability of inflation taken as the 10 -year standard deviation of CPI inflation; Ycurve $=$ Measure of the slope of the yield curve, taken as the difference between lagged short-term interest rates and a lagged moving average of long-term interest rates; GDebt = Ratio of gross-government-debt-to-GDP in excess of $75 \%$; NXD $<0$ net external-debt-to-GDP ratio when the country holds net external assets (taking the value zero for net external debt positions); NXD $>0$ net external-debt-to-GDP ratio (taking the value zero for net external asset positions); $D$ _USA = Dummy variable to capture the possible effects of quantitative easing, taking values of unity for the USA in 2011 and 2012; D_GRC = Dummy variable taking the value unity for Greece in 2012; D_EMU = Dummy variable taking the value of unity for euro area countries over the period 2010-12 to distinguish the post-crisis period for euro area countries. Country dummies (coefficients not reported here, except to note their presence in the final row of the table) take values of unity in 1998 for Korea (the Asia crisis) in 1990 for Spain and Sweden, and 1990-

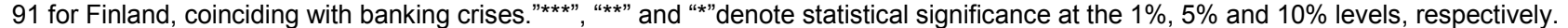

Source: OECD calculations based on OECD Economic Outlook November 2013, IMF World Economic Outlook database, October 2013 data and IMF International Financial Statistics, November 2013. 
11. The effect of changes in government debt varies with the equation specification, with the simplest specification, [equation (1) in Table 1] which is also closest to the preferred equation of Turner and Spinelli (2012) implying each percentage point increase in government debt raises the interest-rate differential by about 5 basis points, which is similar to the effect estimated in Turner and Spinelli (2012). However, as net external debt is included and the post-crisis period is differentiated for euro area countries (as discussed below) this effect falls to 2-4 basis points.

12. The inclusion of an additional variable for the ratio of net-external-debt-to-GDP ("NXD", taking negative values when gross external assets exceed gross external liabilities) is statistically significant [equation (2) in Table 1] and implies that an increase in the net external debt-to-GDP ratio of 1 percentage point will raise interest rates by about 3 basis points. Further estimations consider whether the effect of changes in net external assets and net external debt are symmetric, by distinguishing whether a country has net external debt ("NXD>0", taking positive values when a country has net external debt but is zero when a country has net external assets) or net external assets ("NXD $<0$ ", taking negative values when a country has net external assets, but is zero when a country has net external debt). When both variables are included in the specification [equation (3)], the coefficient on the former is greater (as well as statistically more significant), implying that the effect on interest rates of a unit increase in the net external debt-to-GDP ratio is larger starting from a position of net external debt than net external assets. The coefficient estimates on net external debt vary when the post-crisis period is differentiated for euro area countries, although the distinction of a larger marginal effect when starting from a position of net external debt than net external assets remains.

13. Examination of the residuals of equations (1) to (4) showed that they were particularly large for euro area countries which had come under financial market pressure in the post-crisis period, so that introducing a post-crisis dummy for euro-area countries considerably improved the fit for these countries. This dummy (taking the value of unity for years after 2009, but only for euro area countries) was significant when multiplied by the government debt or net external debt variables, implying that increased sensitivity of euro area countries to these variables in the post-crisis sample [equations (5) and (6)]. However, the preferred specification improves in terms of fit and parsimony with the introduction of a nonlinear variable which was the product of the dummy variable, government debt and net external debt [equation (7)]. With the exception of Greece in 2012, equation (7) including the non-linear debt variable, tracks the dispersion of interest rates within the euro area reasonably well in the post-crisis period and seemingly much better than some recent studies which have systematically under-predicted the increase in interest rates in euro area periphery countries (Di Cesare, 2012; De Grauwe and Ji, 2012; and Proghosyan, 2012). For this reason, a dummy variable is included for Greece in 2012 in the final preferred equation (8).

14. One weakness of the estimated equations is a tendency for them to systematically over-predict the interest-growth differential in recent years, but especially in 2012 and especially for the larger countries. The inclusion of a dummy for the United States in 2011 and 2012 to capture the effects of quantitative easing is highly significant, but the size of the coefficient suggests a larger effect than found by studies which have specifically focused on trying to identify the magnitude of this effect. The large under-prediction in 2012 for Japan, France, Germany, United Kingdom and the United States as well as smaller countries such as Australia, Norway and Sweden might have alternative explanations: direct effects from quantitative easing measures (in the United States, United Kingdom and Japan) or international spillovers from such measures in other countries; and/or the possibility that in current circumstances the proxy for the slope of the yield curve does not adequately capture the duration over which policy rates are expected to be maintained at low levels. 


\section{Effects of government debt and external debt on interest rates}

15. This section considers the implications of the final preferred specification (equation 8) for the effect of changes in government and external debt. For non-euro area countries, the effect of a 1 percentage point increase in net external debt is to raise interest rates by just about $2 \frac{1}{2}$ basis points (Figure 4 ), which is similar to other estimates in the literature (see Annex 2). However, the effect is not symmetrical, so that an increase in net external assets by 1 percentage point will only lower interest rates by about 1 basis point.

\section{Figure 4. The effect of external debt on the interest-rate-growth-differential}

\section{Percentage points}

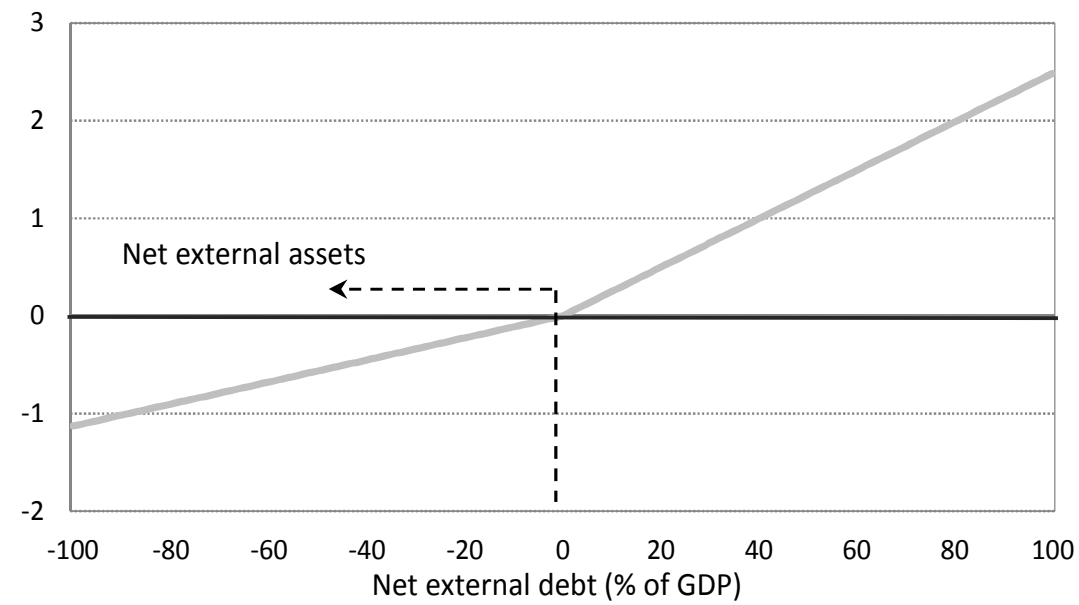

Note: The chart shows the estimated effect of changes in external debt on the interest-growth differential.

Source: OECD calculations made using the coefficients of equation (8) in Table 1.

16. The combined effect of external and government debt on the interest-growth differential for nonEMU countries is additive, as illustrated by the parallel interest-rate schedules for external debt at different levels of government debt shown in Figure 5a. The inclusion of net external debt in the specification implies that the increase in interest rates from an increase in government debt depends on whether it is domestically or externally financed, as shown in Figure 6; precisely, for non-euro area countries, an increase in the government debt ratio (above the $75 \%$ threshold) raises interest rates by $2 \frac{1}{2}$ basis points if domestically financed and $3 \frac{1}{2}$ to 5 basis points if entirely externally financed (the larger effect being for countries starting from an initial position of net external debt).

17. The inclusion of the non-linear debt term has major implications for euro area countries in the post-crisis period, because it suggests that there is an important interaction between government debt and net external debt. The marginal effect of an increase in either government debt or net external debt (or both) on interest rates is very dependent on the initial levels of these variables with a sharply escalating increase in the cost of debt at higher levels of external debt as illustrated by the increasing slope of the interest-rate schedules for external debt as the level of government debt increases in Figure 5b. Thus, the effect of a marginal increase in government debt (above the threshold of $75 \%$ of GDP) on interest rates differs across euro area countries as follows (Figure 6):

- For a euro area country which has no net external debt (like Germany) the effect of an increase in government debt is the same as for non-euro area countries, namely $2 \frac{1 / 2}{2}$ basis points if financed entirely domestically and $3 \frac{1}{2}$ basis points if financed entirely externally. 
- For a country with net external debt of about $25 \%$ of GDP (similar to Italy) the increase in interest rates for a marginal increase in government debt is between $5 \frac{1}{2}$ and 8 basis points (depending on whether it is domestically or externally financed, respectively).

- For a country with initial net external debt of $100 \%$ of GDP (similar to Greece, Portugal and Spain) the corresponding increase in interest rates is between 12 and 15 basis points.

The annual specification considered here cannot capture the higher frequency variation which has been apparent in euro area interest differentials and appears to be driven by financial market sentiment reacting to policy announcements and political events which are not modelled within this framework. Nevertheless, the estimation results do suggest that when financial market tensions are heightened, those countries with a combination of high external debt and government debt are most exposed, as suggested by Gros (2012).

\section{Figure 5. Risk premia effects of different combinations of external and government debt Percentage points}

(a) Non-euro area countries

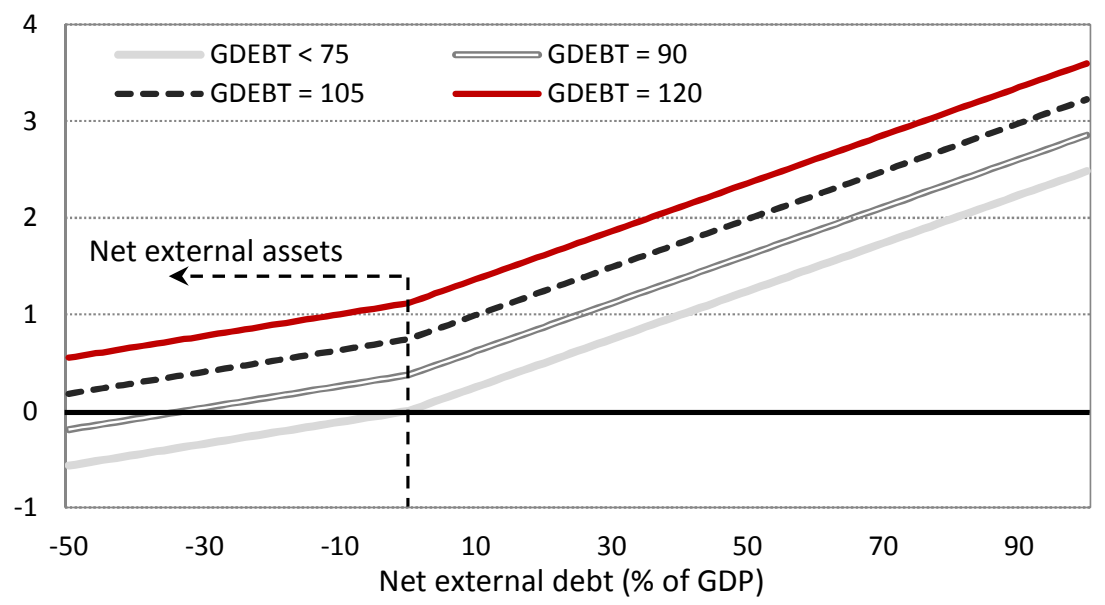

(b) Euro area countries

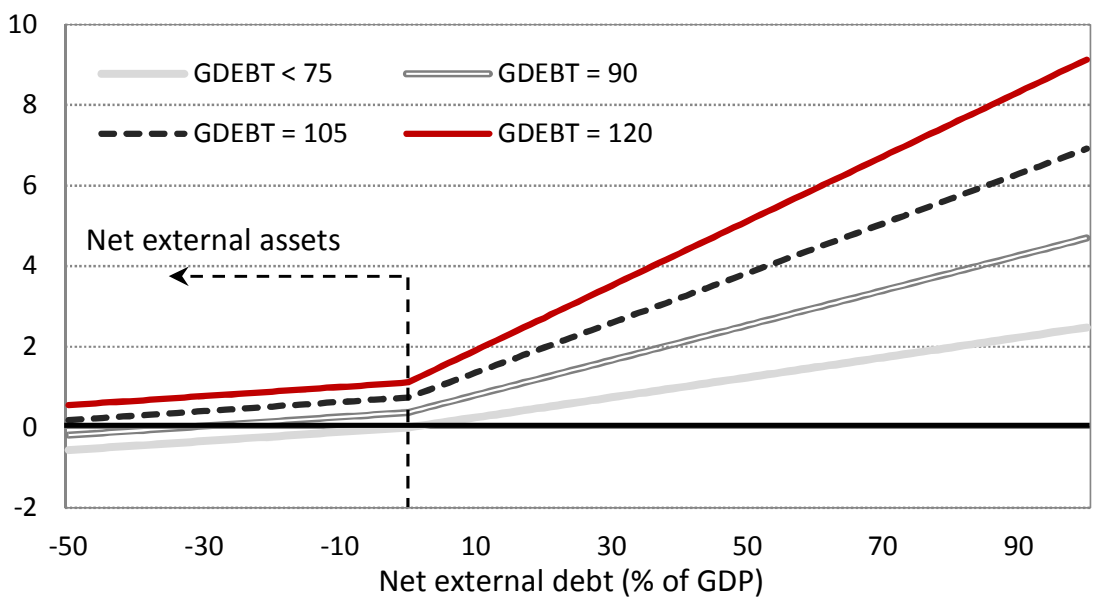

Note: The charts show the estimated effect of different combinations of external and government debt on the interest-growth differential.

Source: OECD calculations based on the coefficients of equation (8) in Table 1. 


\section{ECO/WKP(2013)95}

Figure 6. Risk premia effects of an increase in the government-debt-to-GDP ratio by 1 percentage point

Basis points

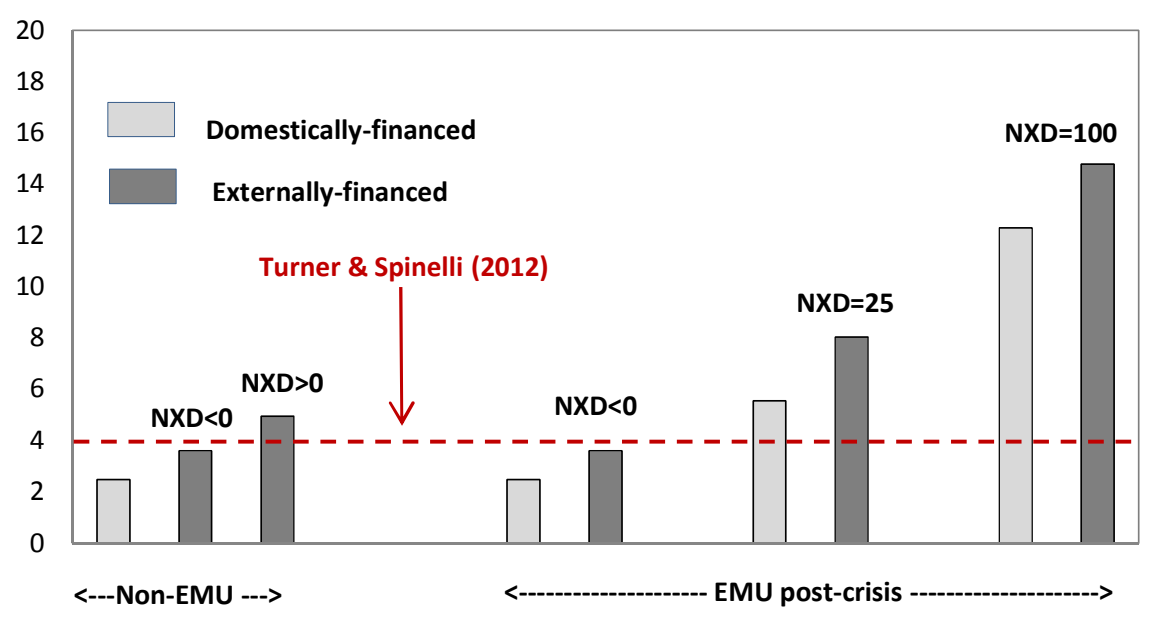

Note: The chart show the effect on long-term interest rates of an increase in the government debt-to-GDP ratio by one percentage point when the initial ratio exceeds a threshold of $75 \%$. It distinguishes whether the extra government debt is financed domestically (lighter bars) or externally so leading to an equivalent increase in net external debt (NXD) (the darker bars). Following the estimation results, the effects are also distinguished between EMU and non-EMU countries, and for the former countries the effects depends on the initial level of net external debt, the three cases considered to be net external assets and net external debt of $25 \%$ and $100 \%$ of GDP..

Source: OECD calculations made using the estimated coefficients of equation (8) in Table 1. 


\section{BIBLIOGRAPHY}

Bernanke, B. (2005), "The Global Savings Glut and the US Current Account Deficit", speech delivered at the Sandridge Lecture, Virginia Association of Economists, Richmond, Va, 10 March.

Bernanke, B. (2007), “The Global Imbalances: Recent Developments and Prospects”, speech delivered at the Bundesbank Lecture, Berlin, Germany, 11 September.

Bernanke, B., C. Bertaut, L. Pounder De Marco and S. Kamin (2011), "International Capital Flows and the Return to Safe Assets in the United States, 2003-7", Board of Governors of the Federal Reserve System, International Finance Discussion Papers, No.1014, February.

Bruno, G. (2005), "Approximating the Bias of the LSDV Estimator for Dynamic Unbalanced panel Data Models", Economic Letters, Vol. 87.

Catao, L. A. V. and G. M. Milesi-Ferretti (2012), "External Liabilities and Crisis Risk", draft paper IMF, 28 April.

Cecchetti, S., M. Mohanty and F. Zampolli (2011), "The Real Effects of Debt", BIS Working Papers. No.352.

Cheung, C. (2013), "Policies to Support Sustainable Long-Term Growth in New Zealand", OECD Economics Department Working Papers, No.1076.

De Grauwe, P. (2011), “Managing a Fragile Eurozone”, http://www.voxeu.org/article/managing-fragileeurozone.

De Grauwe, P. and Y. Ji (2012), "Mispricing of Sovereign Risk and Multiple Equilibria in the Eurozone", CEPS Working Document No.361.

Di Cesare, A., G. Grande. M. Manna and M. Taboga (2012), "Recent Estimates of Sovereign Risk Premia for Euro-Area Countries", Questioni di Economia e Finanza (Occasional Papers) No.128.

Égert, B. (2010), "Fiscal Policy Reaction to the Cycle in the OECD: Pro- or Counter-Cyclical?", OECD Economics Department Working Papers, No.763.

Égert, B. (2012), "Public Debt, Economic Growth and Nonlinear Effects: Myth or Reality?", OECD Economics Department Working Papers, No.993.

Elmeskov, J. and D. Sutherland (2012), "Post-Crisis Debt Overhang: Growth Implications Across Countries", paper prepared for the Reserve Bank of India's Second International Research Conference 2012, 1-2 February, Mumbai, India. 


\section{ECO/WKP(2013)95}

Escolano, J., A. Shabunina and J .Woo (2011), "The Puzzle of Persistently Negative Interest Rate-Growth Differentials: Financial Repression or Income Catch-Up?”, IMF Working Paper No.11/260.

Haugh, D., P. Ollivaud and D. Turner (2009), "What Drives Sovereign Risk Premiums? An Analysis of Recent Evidence from the Euro Area”, OECD Economics Department Working Papers, No.718.

Kawai, M and P. J. Morgan (2012), “Japan's Post-Triple-Disaster Growth Strategy", ADBI Working Paper 376.

Kumar, M. S. and J. Woo (2010), "Public Debt and Growth”, IMF Working Papers. No.10/174.

Lane, P. R. and G. M. Milesi-Ferreti (2001), "Long-Term Capital Movements", Centre for Economic Policy Research, Discussion Paper No.2873.

Laubach, T. (2009), "New Evidence on the Interest Rate Effects of Budget Deficits and Debt", Journal of the European Economic Association, Vol.7.

OECD (2013a), Economic Surveys: Japan.

OECD (2013b), "Chapter 4 - Growth Prospects and Fiscal Requirements over the Long Term", OECD Economic Outlook, No.93, May.

Proghosyan, T. (2012), "Long-Run and Short-Run Determinants of Sovereign Bond Yields in Advanced Economies", IMF Working Paper WP/12/271.

Reinhart, C. and K. Rogoff (2010), "Growth in a Time of Debt", American Economic Review, Vol.100.

Rose, D. (2010), "The Influence of Foreign Assets and Liabilities on Real Interest Rates", Institute of Policy Studies Working Paper 10/09.

Sutherland, D., P. Hoeller and R. Merola (2012), "Fiscal Consolidation: Part 1. How Much is Needed and How to Reduce Debt to a Prudent Level?", ?", OECD Economics Department Working Papers, No.932.

Turner, D. and F. Spinelli (2012), "Interest-Rate-Growth-Differentials and Government Debt Dynamics", OECD Economic Studies.

Wright, J. (2011), "Term Premia and Inflation Uncertainty: Empirical Evidence from an International Panel Dataset", American Economic Review, Vol.101. 


\section{ANNEX 1. DATA DESCRIPTION}

The data used in this paper cover 22 OECD member countries over the period 1980-2012. These countries were selected to maximise the time span of the panel dataset so that the maximum number of observations per variable would be 636. However, due to the gaps in the data for some countries, particularly Greece, the effective number of observations used in each regression is slightly lower. The exact country coverage of the variables is presented in Table A1.

Most of the data used in this paper are taken from the recently published OECD Economic Outlook No. 94 database, released in November 2013. Data used to construct the measure of the "global savings glut" are extracted from the IMF World Economic Outlook (WEO) database, released in October 2013, while data used for net external debt are sourced from the International Investment Position Statistics of the IMF, using BPM5 data as far as possible and complementing them with BPM6 figures when required.

Although various information on the variables used in the empirical analysis are provided in different sections of the main text, some extra details on the definition and construction of these variables are given below.

The simple model, corresponding to equation (1) in Table 1, includes the following variables:

- The interest-rate-growth differential as dependent variable defined as the difference between the levels of the interest rate on 10-year government bonds and the OECD measure of nominal potential GDP growth smoothed with an HP-filter;

- Inflation volatility is measured as a ten-year standard deviation of CPI inflation;

- The slope of the yield curve is calculated as the difference between lagged short-term interest rates (generally three-month Treasury bill rate) and a four-year lagged average of long-term interest rates on 10-year Treasury bonds;

- A proxy measure of the global savings glut, obtained by combining current account surpluses of Asian emerging economies and main oil exporting countries expressed as percentage of world GDP. Specifically, the two country groups selected from the WEO were "Developing Asia" and "Middle East and North Africa" (for more details on the groups composition see Table A2);

- A variable measuring high government indebtedness is included, and constructed for each country as the excess of the general government debt-to-GDP ratio when this share is above the threshold of $75 \%$ of GDP, and zero otherwise;

This model is subsequently extended with the inclusion of one or more of the following variables:

- A dummy variable taking value unity for Euro area countries over the period 2009 to 2012 and zero elsewhere, designed to exclude the influence of the debt variable and/or the net external debt variable for EMU countries over that specific period, included from equation (5) onwards; 
- Finally, a variable (NXD) measuring the ratio of net external debt to GDP, taking negative values when gross external assets exceed gross external liabilities, is included for equation (2). From equation (3) on two separate variables are included to distinguish whether a country has net external debt (NXD $>0$, which takes positive values when a country has net external liabilities and is zero (rather than negative) when a country has net external assets) or net external assets (NXD $<0$, taking negative values when a country has net external assets and being zero in case the country has net external debt). Both variables are adjusted in the case of Finland in 1999 to smooth the effect of the high-tech bubble, during which an excessive number of shares in Nokia were predominantly held abroad, i.e. by foreign residents.

Table A1. Details on data availability

\begin{tabular}{|c|c|c|c|}
\hline Variable & $\begin{array}{c}\text { Starting } \\
\text { date }\end{array}$ & $\begin{array}{c}\text { Ending } \\
\text { date }\end{array}$ & Exceptions to the starting date \\
\hline $\begin{array}{l}\text { Interest rate - growth differential } \\
\text { (irl-g) } \mathrm{t} \\
\text { dependent variable }\end{array}$ & 1980 & 2012 & $\begin{array}{l}\text { Portugal and New Zealand (1981), Switzerland (1982), Korea (1983), Greece } \\
\text { (1994) }\end{array}$ \\
\hline $\begin{array}{l}\text { Short-term interest rate minus } \\
\text { Long-term interest rate } \\
(\text { irs - irl) } \mathrm{t}\end{array}$ & 1980 & 2012 & Denmark (1981), Sweden (1983), Ireland (1985), Greece (1994), Korea (1992) \\
\hline $\begin{array}{l}\text { Standard deviation of inflation } \\
\mathrm{SD}_{5}(\pi) \mathrm{t}\end{array}$ & 1980 & 2012 & Greece (1997) \\
\hline Global savings glut & 1980 & 2012 & - \\
\hline Debt 75 & 1980 & 2012 & Australia (1988), New Zealand (1993), Greece and Portugal (1995), Ireland \\
\hline $\begin{array}{l}\text { Net external assets as a } \\
\text { percentage of GDP }\end{array}$ & 1980 & 2012 & $\begin{array}{l}\text { Australia (1986), Belgium (1981), Denmark (1991), France (1989), Greece (1999), } \\
\text { Ireland (2001), New Zealand (1989), Portugal (1996), Spain (1981), Switzerland } \\
\text { (1983), Sweden (1982) }\end{array}$ \\
\hline
\end{tabular}


ECO/WKP(2013)95

Table A2. List of countries composing the different aggregates considered in the empirical analysis

\begin{tabular}{ll}
\hline Country aggregate & Countries \\
\hline OECD 22 & $\begin{array}{l}\text { Australia, Austria, Belgium, Canada, Denmark, Finland, France, Germany, Greece, Ireland, Italy, Japan, } \\
\text { Korea, Netherlands, New Zealand, Norway, Portugal, Spain, Sweden, Switzerland, United Kingdom, United } \\
\text { States. }\end{array}$ \\
\hline G 7 Canada, France, Germany, Italy, Japan, United Kingdom, United States. \\
\hline Selected EMU countries & $\begin{array}{l}\text { Austria, Belgium, Finland, France, Greece, Ireland, Italy, The Netherlands, Portugal, Spain. } \\
\text { Developing Asia }\end{array}$ \\
\hline $\begin{array}{l}\text { Afghanistan, Bangladesh, Bhutan, Brunei, Cambodia, China, Fiji, India, Indonesia, Kiribati, Lao People's } \\
\text { Democratic Republic, Malaysia, Maldives, Myanmar, Nepal, Pakistan, Papua New Guinea, Philippines, } \\
\text { Samoa, Solomon Islands, Sri Lanka, Thailand, Democratic Republic of Timor-Leste, Tonga, Tuvalu, } \\
\text { Vanuatu, Vietnam. }\end{array}$ \\
\hline $\begin{array}{l}\text { Middle East and North } \\
\text { Africa }\end{array}$ & $\begin{array}{l}\text { Algeria, Bahrain, Djibouti, Egypt, Islamic Republic of Iran, Iraq, Jordan, Kuwait, Lebanon, Libya, Mauritania, } \\
\text { Morocco, Oman, Qatar, Saudi Arabia, Sudan, Syrian Arab Republic, Tunisia, United Arab Emirates, Republic } \\
\text { of Yemen. }\end{array}$ \\
\hline
\end{tabular}




\section{ANNEX 2. A BRIEF SELECTIVE SUMMARY OF THE LITERATURE RELATING EXTERNAL DEBT TO INTEREST RATES}

There are a number of empirical studies which find a link between a country's external asset/debt position and its domestic interest rates, although exact comparisons are difficult because of the precise setup of the empirical estimation:

- Lane and Milesi-Ferreti (2001) find evidence of an inverse relationship between interest rates on government bonds and net foreign asset positions such that a 20 percentage point increase in the ratio of net foreign liabilities to exports position is associated with a 50 basis point increase in real interest rates. To put this result on a more comparable basis to other results discussed below, this would imply that, for an OECD country with a typical export-to-GDP ratio of about $40 \%,{ }^{5}$ an increase in net external debt of 1 percentage point of GDP would raise domestic interest rates by about 6 basis points. The same analysis suggests a marginally significant positive impact on interest rates from government debt.

- Rose (2010) employs a panel data set of 20 advanced economies over the period 1980-2004 and concludes that interest rates are sensitive to net international investment positions and that a 1 percentage point increase in the ratio of net external debt to GDP will typically be associated with an increase of 2 basis points in real interest rates.

- Cheung (2013) using a panel regression on 25 OECD countries over the period 1970-2007, finds that a 1 percentage point increase in net foreign debt as a share of GDP is associated with an increase in real long-term interest rates of 1.3 basis points. The estimation period is not extended to include more recent observations to "exclude the extraordinary effect of the financial crisis". No statistically significant effect on interest rates from government debt was found.

In summary, the three studies considered above find that an effect of an increase in the net external debt to GDP ratio of about 1 percentage point raises interest rates by between 1.3 and 6 basis points. All of these studies are based on a pre-crisis estimation period.

5. The inter-quartile range of export-to-GDP ratios among OECD countries is about $30 \%$ to $65 \%$ implying an increase of between 4 and 8 basis points for a 1 percentage point increase in net external debt. 


\section{ANNEX 3. SENSITIVITY OF THE RESULTS TO RELAXING THE RESTRICTION ON NOMINAL POTENTIAL GROWTH}

The dependent variable in the estimations reported in the main paper, following Turner and Spinelli (2012), is always the differential between nominal long-term interest rates and nominal potential growth. To the extent that the equation is considered to provide an explanation for long-term interest rates, this effectively imposes a unit coefficient on nominal potential growth. If this restriction is relaxed so that the coefficient on potential growth is estimated, the freely estimated coefficient is estimated to be about 0.7 and is significantly very different from both zero and unity (see table below). There is a relatively small reduction in the estimated coefficients on government debt and external debt, although the coefficient on the yield curve increases by a factor of a half and on inflation variability more than doubles.

Table A3. Panel regression results from relaxing the restriction on nominal potential growth

Sample 1980-2012, 22 OECD countries

\begin{tabular}{|c|c|c|}
\hline Dependent variable & IRL - G & IRL \\
\hline G & 1.00 [Implicit] & $0.702^{* * *}$ \\
\hline $\operatorname{var}(\pi)$ & $0.215^{* * *}$ & $0.485^{* * *}$ \\
\hline Ycurve & $0.202^{* * *}$ & $0.300^{* * *}$ \\
\hline S Glut & $-1.784 * * *$ & -1.964 *** \\
\hline GDebt & $0.043 * * *$ & $0.033^{* * *}$ \\
\hline$N X D>0$ & $0.045^{* * *}$ & $0.035^{* * *}$ \\
\hline$N X D<0$ & $0.012 * *$ & $0.013^{* *}$ \\
\hline Number of observations & 609 & 609 \\
\hline Adj R-squared & 0.39 & 0.74 \\
\hline S.E. of regression & 1.79 & 1.74 \\
\hline Country fixed effects & yes & yes \\
\hline Country dummies & yes & yes \\
\hline
\end{tabular}

Note: $\quad$ Variable definitions as follows: IRL = Nominal long-term interest rates (percentage points); $\mathrm{g}=$ nominal potential growth (\% per annum); $\operatorname{Var}(\pi)=$ measure of the variability of inflation taken as the 10-year standard deviation of CPI inflation; Ycurve $=$ Measure of the slope of the yield curve, taken as the difference between lagged short-term interest rates and a lagged moving average of long-term interest rates; GDebt = Ratio of gross-government-debt-to-GDP in excess of $75 \%$; NXD<0 net external-debt-to-GDP ratio when the country holds net external assets (taking the value zero for net external debt positions); NXD>0 net external-debt-to-GDP ratio (taking the value zero for net external asset positions). Statistical significance at the $1 \%, 5 \%$ and $10 \%$ levels is denoted by "***", "*** and "*”, respectively.

Source: The equation in the first column is equation (3) from Table 1 in the main paper, whereas the equation in the second column is a re-estimate of this same equation but with the unit restriction on nominal potential growth relaxed.

The finding of a coefficient on potential growth of less than unity implies that higher potential growth will improve (i.e. reduce) the interest-rate-growth differential and so improve the prospects for fiscal sustainability of indebted countries. This is turn suggests that structural reforms which boost potential growth can also contribute to improving fiscal sustainability. 
ECO/WKP(2013)95

\section{WORKING PAPERS}

The full series of Economics Department Working Papers can be consulted at www.oecd.org/eco/workingpapers/

1102. The state of the banking sector in Europe

(December 2013) by Dirk Schoenmaker and Toon Peek

1101. Getting Irish youth on the job track

(December 2013) by Alberto Gonzalez Pandiella

1100. New econometric estimates of long-term growth effects of different areas of public spending (December 2013) by Omar Barbiero and Boris Cournède

1099. Cross-country spillovers from fiscal consolidations

(December 2013) by Antoine Goujard

1098. Informal employment in Russia: Definitions, incidence,determinants and labour market segmentation

(November 2013) by Hartmut Lehmann and Anzelika Zaiceva

1097. Capacity needs in the automobile industry in the short- to medium run

(November 2013) by Caroline Klein and Isabell Koske

1096. Environmental policies and productivity growth - a critical review of empirical findings

(November 2013) by Tomasz Koźluk and Vera Zipperer

1095. Green growth challenges and the need for an energy reform in Mexico

(November 2013) by Carla Valdivia de Richter

1094. From bricks to brains: increasing the contribution of knowledge-based capital to growth in

Ireland

(November 2013) by David Haugh

1093. China's march to prosperity: reforms to avoid the middle-income trap

(November 2013) by Vincent Koen, Richard Herd and Sam Hill

1092. Multi factor productivity with natural capital

(November 2013) by Nicola Brandt, Paul Schreyer and Vera Zipperer

1091. Growth-promoting policies and macroeconomic stability

(November 2013) by Douglas Sutherland and Peter Hoeller

1090. Policies for inclusive urbanisation in China

(October 2013) by Vincent Koen, Richard Herd, Xiao Wang and Thomas Chalaux

1089. Fiscal devaluation - can it help to boost competitiveness?

(October 2013) by Isabell Koske

1088. How to achieve growth- and equity-friendly fiscal consolidation? A proposed methodology for instrument choice with an illustrative application to OECD countries

(October 2013) by Boris Cournède, Antoine Goujard and Álvaro Pina 
1087. Improving school-to-work transition in New Zealand

(September 2013) by Alexandra Bibbee

1086. The agri-food situation and policies in Switzerland

(September 2013) by Peter Jarrett and Charlotte Moeser

1085. Japan's challenging debt dynamics

(August 2013) by Yvan Guillemette and Jan Strasky

1084. Transitions in and out of unemployment among young people in the Irish recession

(August 2013) by Elish Kelly, Seamus McGuinness, Philip O'Connell, David Haugh and Alberto González Pandiella

1083. Is there convergence of Russia's regions? Exploring the empirical evidence: 1995-2010

(August 2013) by Hartmut Lehmann and Maria Giulia Silvagni

1082. The benefits and costs of highly expansionary monetary policy

(August 2013) by Łukasz Rawdanowicz, Romain Bouis and Shingo Watanabe

1081. The effectiveness of monetary policy since the onset of the financial crisis

(August 2013) by Romain Bouis, Łukasz Rawdanowicz, Jean-Paul Renne, Shingo Watanabe and Ane Kathrine Christensen

1080. Responding to key well-being challenges in Austria

(August 2013) by Rauf Gönenç, Oliver Röhn, Christian Beer and Andreas Wörgötter

1079. Austria's well-being goes beyond GDP

(August 2013) by Oliver Röhn, Rauf Gönenç, Christian Beer and Romina Boarini

1078. Improving fiscal federal relations for a stronger Mexico

(August 2013) by Aida Caldera Sánchez

1077. Deleveraging: challenges, progress and policies

(August 2013) by Romain Bouis, Ane Kathrine Christensen and Boris Cournède

1076. Policies to support sustainable long-term growth in New Zealand

(July 2013) by Calista Cheung

1075. Do structural policies affect macroeconomic stability?

(July 2013) by Volker Ziemann

1074. A simple fiscal stress testing model - case studies of Austrian, Czech and German economies (July 2013) by Ondra Kamenik, Zdenek Tuma, David Vavra and Zuzana Smidova

1073. Road connectivity and the border effect: evidence from Europe

(July 2013) by Henrik Braconier and Mauro Pisu

1072. Fiscal consolidation across government levels. Part 3: Intergovernmental grants, pro- or counter-cyclical?

(July 2013) by Hansjörg Blöchliger and Balázs Égert 